\title{
RECENZJE
}

\section{Waldemar Jan Dziak, Anatomia władzy totalnej. Przypadek Korei Pótnocnej, Instytut Studiów Politologicznych PAN, Warszawa 2018, ss. 260}

\author{
(ㄷ) (1) $\Theta$ \\ http://dx.doi.org/10.12775/KLIO.2019.008
} W 2018 roku Instytut Studiów Politycznych Polskiej Akademii Nauk Pótnocna - atomowe mocarstwo ${ }^{1}$ napisane wspólnie z Jerzym Bayerem oraz właśnie Anatomia wtadzy totalnej. Przypadek Korei Pótnocnej², która została przedstawiona w niniejszym tekście.

Recenzowana publikacja liczy 260 stron, z których na część zasadniczą pracy składa się około 150, a resztę stanowią załączniki oraz bibliografia. Całość jest skonstruowana w dość niekonwencjonalny sposób, narracja w pracy ma charakter autobiograficzny, przez co przyjęła wygląd wywiadu przeprowadzanego przez autora z samym sobą. Główna część pracy nosi podtytuł „Korea Północna oczami politologa”. Jest ona podzielona pyta-

1 J. Bayer, W.J. Dziak, Korea Pótnocna - atomowe mocarstwo, Warszawa 2018.

2 W. J. Dziak, Anatomia wtadzy totalnej. Przypadek Korei Pótnocnej, Warszawa 2018. 
niami, na które autor odpowiada. Niestety, w książce nie ma żadnego spisu tych pytań, co utrudnia czytelnikowi poruszanie się po tekście.

Autor na początku publikacji opowiada, skąd wzięła się u niego fascynacja Koreańską Republiką Ludowo-Demokratyczną. Wspomina swoje wyprawy najpierw do chińskiej, a później północnokoreańskiej ambasady. Wskazuje na determinanty odpowiadające za tę fascynację, wymieniając m.in. konflikt sowiecko-chiński, pragnienie większej niezależności dla PRL w obrębie bloku komunistycznego, ale również poglądy jego rodziców, które były zdecydowanie bardziej prawicowe niż chciałaby tego ówczesna władza.

Dopiero około strony 40 publikacji autor zaczyna opisywać drogę Kim Ir Sena do władzy absolutnej, jego własny pomysł na komunizm. Ukazuje poczynania Kima oraz szereg zbiegów okoliczności, które pozwoliły na stworzenie w Korei Północnej takiego ustroju. Ukazane zostały również główne aspekty dziedziczenia władzy w KRL-D oraz dogmaty ideologii Dżucze panującej w tym kraju. Pokazuje bezwzględność reżimu, przywołując morderstwa popełnione z rozkazu Kim Dzong Una na jego najbliższych, tj. wuju Jong Song Thaek ${ }^{3}$ (mężu Kim Kyŏng Hŭi ${ }^{4}$ ) oraz Kim Dzong Namie (przyrodnim bracie Kim Dzong Una). Pod koniec pracy autor opisuje drogę KRL-D do statusu mocarstwa atomowego, wytyka błędy popełnione przez świat demokratyczny, które w konsekwencji doprowadziły do aktualnego stanu rzeczy.

Książka Anatomia wtadzy totalnej. Przypadek Korei Pótnocne jest uzupełniona aż o 22 aneksy. Pierwszym z nich jest Noworoczne orędzie Kim

${ }^{3}$ Jong Song Theak pełnił bardzo prestiżowe funkcje za rządów Drugiego Przywódcy, w praktyce był drugą osobą w państwie. Piastował stanowiska: wicedyrektora Departamentu Organizacji i Przywództwa, dyrektora Banku Inwestycyjnego Taepong, członka Biura Politycznego KC PPK, członka Centralnej Komisji Wojskowej przy KC PPK, członka Stałego Komitetu BP KC PPK, członka CKW BPR, członek KC, był wiceprzewodniczącym Krajowej Komisji Obrony, posłem i czterogwiazdkowym generałem, a Kim Dzong Il na łożu śmierci namaścił go na przewodnika Kim Dzong Una.

${ }^{4}$ Kim Kyŏng Hŭi - córka Kim Ir Sena, kierownik departamentu przemysłu lekkiego PPK, członkini BP KC, miała stopień generała, zdegradowana i odsunięta od władzy po egzekucji męża. 
Dzong Una z 2018 roku, w którym to Król Gwiazdy Polarnej ${ }^{5}$ wychwala osiągnięcia KRL-D w sferze atomowo-rakietowej, ale równocześnie pisze o polepszeniu stosunków międzykoreańskich. Następny odwołuje się do delegacji północnokoreańskiej na Igrzyska Olimpijskie, które odbyły się w Pjongczangu (Republika Korei). Większość z aneksów stanowią oficjalne oświadczenia prasowe $\mathrm{KCNA}^{6}$ dotyczące wizyt dyplomatycznych oraz komunikaty poszczególnych ministerstw. Wśród nich znajduje się również „Wspólne oświadczenie Kim Jong Una i Trumpa”. Ostatnim, 22 aneksem jest wspomnienie byłego więźnia obozu w Korei Północnej Lee Baeka-Lyonga zatytułowane „Byłem więźniem obozu dla więźniów politycznych w Korei Północnej: jak nie udało mi się uciec”. Właśnie ten aneks najlepiej obrazuje sposób, w jaki działa władza totalna w KRL-D oraz poza jej granicami, dzięki czemu czytelnik może pojąć rozmiar niegodziwości, jakich dopuszczała i dopuszcza się dynastia Kimów.

Z wyjątkiem ostatniego, wszystkie aneksy są dostępne na stronie Międzynarodowej Inicjatywy Przyjaźni Explor DPRK (https://pl.exploredprk. $\mathrm{com} /$ ) w języku polskim, więc są ogólnodostępne dla zainteresowanych. $\mathrm{Z}$ tego względu można się zastanawiać, czy ich publikowanie w książce było konieczne.

Mimo że recenzowana monografia posiada dość rozbudowaną bibliografię, to jednak w tekście najczęściej czytelnik napotyka odwołania do poprzednich prac autora.

Publikacja wyróżnia się z pewnością na tle innych prac o podobnej tematyce, zwłaszcza pod względem konstrukcji, co stanowi jej zarówno mocny, jak i słaby element. Jak już wcześniej wspomniałam, monografii brakuje rozbudowanego spisu treści, z drugiej strony w połączeniu z formą autowywiadu pozwala to autorowi na poruszenie kwestii związanych z Koreą Północną w bardzo nowatorski, ciekawy sposób. Pewne wątpliwości może budzić przyjęcie takiej formy dla pozycji naukowej. Dodatkowo, pierwsze 40 stron publikacji zostało poświęcone młodości autora, co w żaden sposób

5 Jeden z tytułów Kim Dzong Una: W.J. Dziak, K. Sajewski, Korea Pótnocna Wewnętrzne Wektory Trwania, Warszawa 2016, s. 217.

${ }^{6} \mathrm{KCNA}$ - ang. Korean Central News Agency, Koreańska Centralna Agencja Prasowa. 
nie wiąże się z tematyką pracy i powinno zostać raczej zachowane do autobiografii, a nie tekstu naukowego na temat władzy w KRL-D.

W zasadniczej części pracy autor już nie odbiega od tematu i w sposób jasny tłumaczy czytelnikowi realia związane z Koreańską Republiką Ludowo-Demokratyczną, w której, jak twierdzi, na cztery wyrazy przypadają aż trzy kłamstwa ${ }^{7}$. Tym samym daje powód do refleksji na temat tego tworu. Autor zgrabnie określa główne założenia Ideologii Dżucze ${ }^{8}$ i kimirsenizmu9, wspomina o polityce Songun ${ }^{10}$, której niewątpliwym efektem jest aktualny status Korei Północnej jako mocarstwa atomowego. Profesor Dziak wskazuje na zaniedbania, jakich dopuścił się Zachód, oraz piętnuje państwa, które przyczyniły się do rozwoju potencjału atomowo-rakietowego KRL-D.

Tę pozycję wśród innych dzieł prof. W.J. Dziaka można nazwać esencją jego twórczości. Zawiera w sobie kwestie poruszane już wcześniej przez autora w poprzednich publikacjach, np. Kim Ir Sen. Dzieto i polityczne wizje ${ }^{11}$, gdzie autor bardziej skupił się na ideologii Dżucze; Korea Pótnocna, U źródet

7 W. J. Dziak, Anatomia wtadzy, s. 107.

${ }^{8}$ Dżucze - ideologia panująca w KRL-D, została stworzona za panowania Kim Ir Sena. Stawia człowieka w centrum (przeciwieństwie do marksizmu-leninizmu). Ma cztery główne założenia: Dżucze w ideologii, niezależność w polityce, samodzielność w ekonomice, samodzielność w obronie kraju. N. Levi, Korea Pótnocna - poszukując prawdy, Warszawa 2012, s. 36-41; Ł. Smalec, U źródet dżucze, [w:] Pótwysep Koreański wyzwania i zagrożenia, red. J. Rowiński, O. Pietrowicz, Toruń 2014, s. 13-33.

${ }^{9}$ Kimirsenizm - nazwa zaproponowana przez Kim Dzong Ila na określenie całości myśli politycznych Kim Ir Sena, które są znacznie szersze niż same idee Dżucze. Pojęcie to zawiera w sobie również metody Dżucze, filozofię Dżucze oraz teorię Dżucze. Kim Ir Sen, O wykorzenieniu dogmatyzmu i formalizmu $i$ ustanowieniu Dżucze w pracy ideologicznej, Phenian 1971, s. 20; W.J. Dziak, A. Faliński, W kraju Orwella. Uwagi o funkcjonowaniu pótnocnokoreańskiego państwa totalitarnego, Warszawa 1994, s. 53.

${ }^{10}$ Songun - „umacniać jak monolit własne siły rewolucji, pewnie bronić Ojczyzny i usilnie rozwijać budowanie socjalistyczne jako całość, uznając kwestię militarne za najważniejsze w działalności państwa i traktując Armię Ludową za główny oddział rewolucji” - Sungun i prestiż Koreańskiej Republiki Ludowo - Demokratycznej, Biuletyn Ambasady KRL-D w Polsce, http://krld.pl/krld/czytelniateksty/biuletyny//025\%20Songun\%20i\%20 prestiz\%20KRLD.pdf, s. 3 [dostęp:16.12.2018].

11 W. J. Dziak, Kim Ir Sen, Dzieto i polityczne wizje, Warszawa 2000. 
rodzinnej sukcesji wtadzy ${ }^{12}$, publikacji tłumaczącej zasady działania pierwszej na świecie komunistycznej dynastii, czy Korea Pótnocna. Wewnętrzne Wektory Trwania ${ }^{13}$, ukazujące przewagę reżimu północnokoreańskiego nad innymi, jaką jest jego trwałość. Podsumowując, książa Anatomia wtadzy totalnej. Przypadek Korei Pótnocnej stanowi bardzo przydatne kompendium wiedzy na temat tak bardzo zamkniętego kraju, jakim jest Korea Północna. Publikacja ta będzie cennym nabytkiem dla każdego zainteresowanego sytuacją w KRL-D oraz jej zewnętrznymi konsekwencjami.

Całość jest napisana bardzo przystępnym językiem, została oparta, jak sam autor wspomina we wstępie, na czterdziestoletnim doświadczeniu naukowym Profesora w badaniu tego niesamowitego i niepowtarzalnego na skalę światową kraju. Możemy jedynie ubolewać że W.J. Dziak, zawierając w książce wątki autobiograficzne, nie przedstawił szerzej ewolucji swoich poglądów na temat idei Dżucze, ponieważ wcześniej zdarzało mu się wyrażać dla nich uznanie, a nawet podziw ${ }^{14}$.

Daria Tuszyńska (UMK Toruń)

ORCID: 0000-0002-1913-9200

12 Idem, Korea Pótnocna, U źródet rodzinnej sukcesji wtadzy, Warszawa 2009.

13 W. J. Dziak, K. Sajewski, Korea Pótnocna. Wewnętrzne Wektory Trwania, Warszawa 2016.

${ }^{14}$ W. J. Dziak, Koncepcja “Dżucze” Kim Ir Sena, “Studia Nauk Politycznych”, 1983, nr 1-2, s.65-80. 